\title{
Successful Management of Congenital Glottic Web Using Plasma Ablation and Fibrin Glue in an Infant: A Case Report
}

\author{
Balaji Ramamourthy ${ }^{1}$, Anant Basotia ${ }^{2}$, Divya Jain ${ }^{3}$, Joseph L Mathew ${ }^{4}$, Ramandeep Virk ${ }^{5}$
}

\begin{abstract}
Congenital laryngeal webs are rare anomalies usually diagnosed in infancy, that is, children presented with respiratory difficulty or dysphonia. Diagnosis is made by laryngobronchoscopy. Various options such as endoscopic release with LASER, cold instruments with mitomycin C application, and open procedures are mentioned. We describe the usage of plasma ablation for the endoscopic release of glottic web and application of fibrin glue to prevent restenosis.

Keywords: Endoscope, Fibrin glue, Glottic web.

Journal of Postgraduate Medicine, Education and Research (2020): 10.5005/jp-journals-10028-1370
\end{abstract}

\section{INTRODUCTION}

Laryngeal webs account for $5 \%$ of congenital anomalies of larynx. ${ }^{1}$ About $75 \%$ occur at glottic level. ${ }^{2}$ Failure of the epithelial lamina (EL) to recanalize gives rise to range of disorders that include laryngeal webs and stenosis. ${ }^{3}$ Anterior laryngeal webs may be associated with deletions of chromosome 22q11.2, which results in a range of phenotypes that include DiGeorge syndrome, velocardiofacial syndrome, and conotruncal heart malformations. ${ }^{4}$

We present a case of an infant with stridor and associated aphonia secondary to glottic web managed with plasma ablation and fibrin glue endoscopically. Use of fibrin glue for prevention of recurrence of glottic web is being described for the first time in literature.

\section{Case Description}

A 11-month-old infant presented with difficulty in breathing turning into noisy breathing ON and OFF since birth; the infant also had aphonia and weak whispery cry. The child was diagnosed with hypothyroidism and the presenting complaints were attributed to it; the child was prescribed with thyroxine $100 \mu \mathrm{g}$. Since there was no improvement in symptoms, the child was referred to pediatric pulmonology department of our center. Fiberoptic bronchoscopy revealed congenital laryngeal web. Otolaryngology consultation was sought and patient was planned for bronchoscopic assessment under general anesthesia. Examination revealed a thin membranous web between the true vocal folds and progressively thinning out posteriorly to cover approximately $70 \%$ of glottis. Subglottis was free from extension (Cohen's type III glottic web).

Endoscope-assisted plasma ablation (Smith and Nephew, USA) release of the web was performed. A $0^{\circ} 4 \mathrm{~mm}$ endoscope, Miller's laryngoscope blade, and plasma ablation were used for this procedure. ${ }^{5}$ The assistant inserts the laryngoscope blade into the oral cavity and a 4-mm nasal endoscope is inserted through the Miller blade (Fig. 1). The surgeon introduces the microlaryngeal coblation wand into the oral cavity (Fig. 2). The web is completely excised using plasma ablation (Fig. 3), and the fibrin glue (Tisseel, Baxter Corporation, Deerfield, Illinois, USA) is applied topically to form a film over bilateral vocal folds (Fig. 4).

\footnotetext{
1,2Department of Otorhinolaryngology, Postgraduate Institute of Medical Sciences and Research, Chandigarh, India

${ }^{3}$ Department of Anesthesiology, Postgraduate Institute of Medical Sciences and Research, Chandigarh, India

${ }^{4}$ Department of Pediatric Pulmonology, Postgraduate Institute of Medical Sciences and Research, Chandigarh, India

${ }^{5}$ Department of ENT, Postgraduate Institute of Medical Sciences and Research, Chandigarh, India

Corresponding Author: Ramandeep Virk, Department of ENT, Postgraduate Institute of Medical Sciences and Research, Chandigarh, India, Phone: +919814222220, e-mail: virkdoc@hotmail.com

How to cite this article: Ramamourthy B, Basotia A, Jain D, et al. Successful Management of Congenital Glottic Web Using Plasma Ablation and Fibrin Glue in an Infant: A Case Report. J Postgrad Med Edu Res 2020;54(2):56-58.

Source of support: Nil

Conflict of interest: None
}

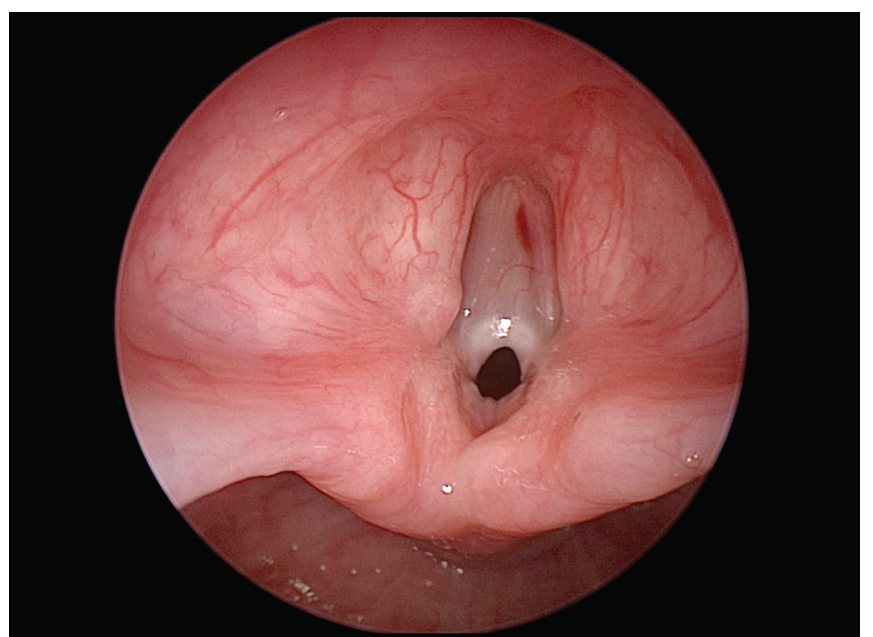

Fig. 1: Laryngoscopy examination using Miller's blade showing grade III congenital glottic web

(0) The Author(s). 2020 Open Access This article is distributed under the terms of the Creative Commons Attribution 4.0 International License (https://creativecommons. org/licenses/by-nc/4.0/), which permits unrestricted use, distribution, and non-commercial reproduction in any medium, provided you give appropriate credit to the original author(s) and the source, provide a link to the Creative Commons license, and indicate if changes were made. The Creative Commons Public Domain Dedication waiver (http://creativecommons.org/publicdomain/zero/1.0/) applies to the data made available in this article, unless otherwise stated. 


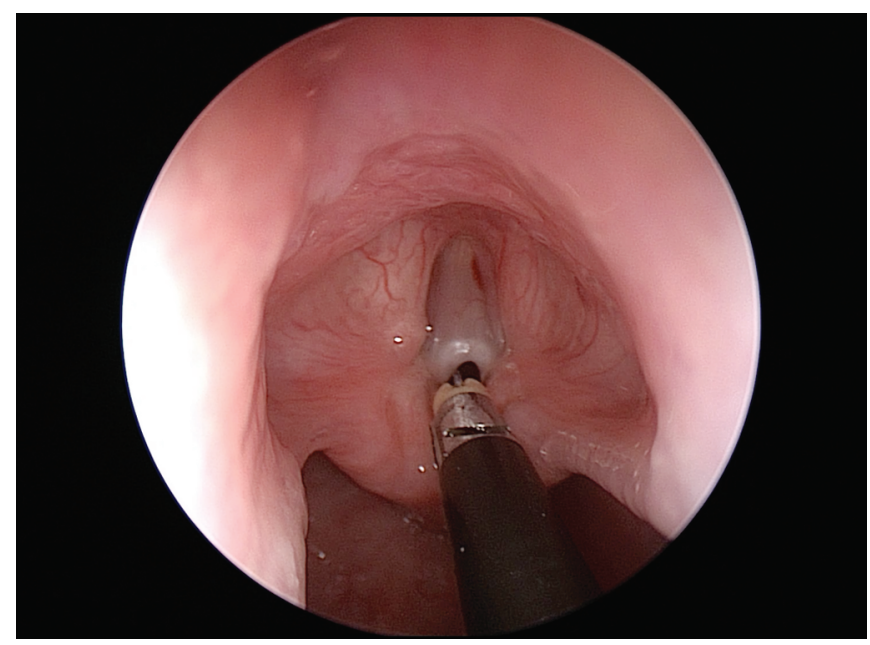

Fig. 2: Glottic web being released using coblation wand

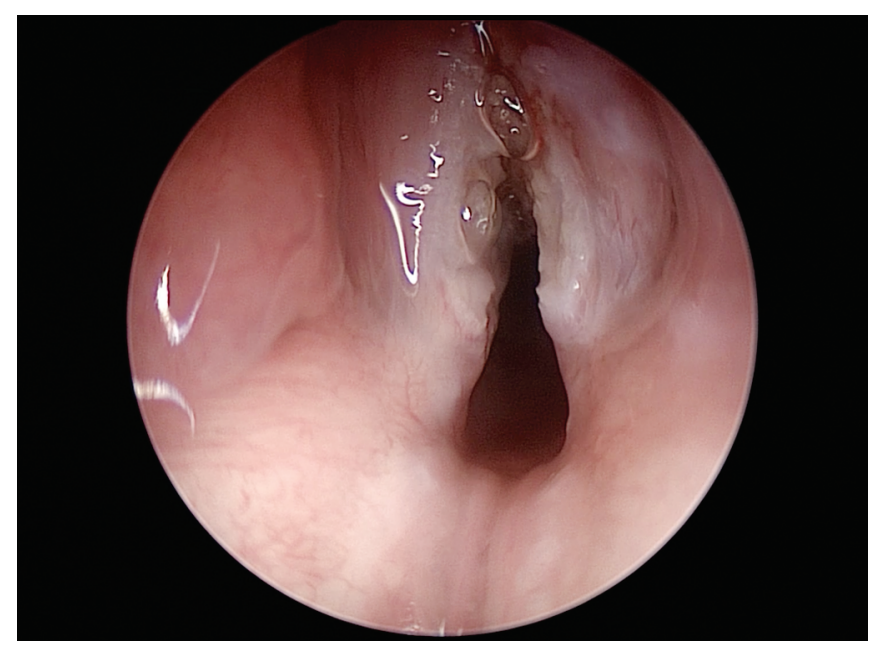

Fig. 4: Application of fibrin glue along the medial border of true vocal cord to prevent restenosis

\section{Discussion}

Incomplete canalization of larynx during embryogenesis results in a glottic or very rarely a supraglottic web. The majority involves the anterior glottis, fusing the vocal cords along a variable part of their length. They are typically diagnosed in the neonatal period.

Glottic webs are classified by Cohen et al. ${ }^{5}$ into Cohen's type I: type I defines an anterior web involving $35 \%$ or less of the glottis, type II is anterior involving $35 \%-50 \%$, type III anterior covering $50 \%-75 \%$, and type IV $75-99 \%$ of the glottis.

Type I presents with mild hoarseness and type IV with aphonia or severe airway obstruction requiring a tracheotomy.

Fiberoptic laryngoscopy is mandatory to confirm the degree of airway compromise. Computed tomography virtual bronchoscopy and magnetic resonance imaging may be useful but have significant shortcomings and are not yet well-established tools.

A web that causes airway obstruction and hoarseness warrants surgical intervention. The primary goal is to provide an adequate airway and to achieve a good voice quality. For limited involvement, endoscopic approach will often be successful. ${ }^{6}$ It

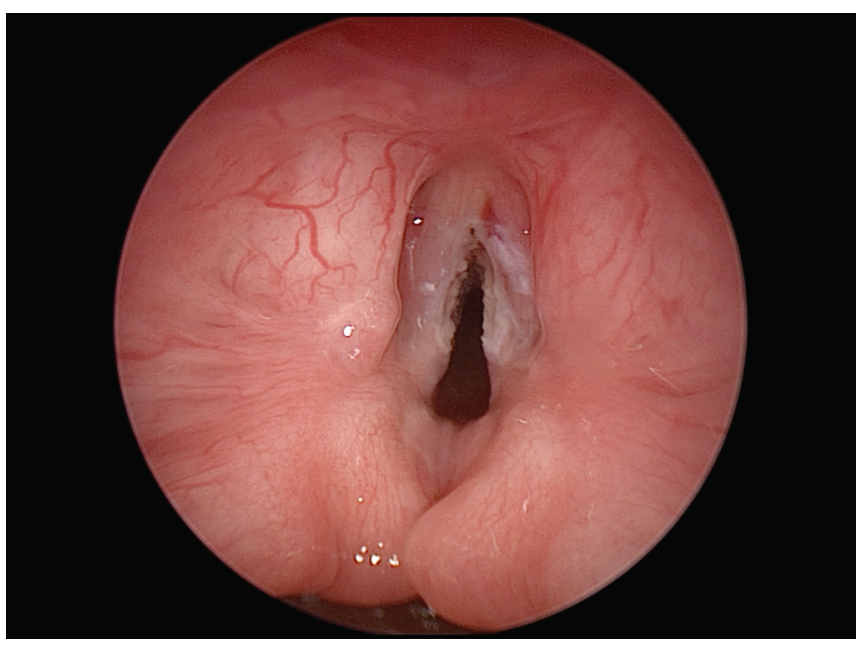

Fig. 3: Appearance of larynx following glottic web release

includes an endolaryngeal mucosal flap or endoscopic placement of a keel. Endoscopic release followed by mitomycin application has also been described. External techniques include laryngofissure with division of the web and keel insertion or stenting and laryngotracheal reconstruction. ${ }^{7}$

Our patient was diagnosed to have Cohen's type III glottic web with no subglottic extension on fiberoptic bronchoscopy and was managed with endoscope-assisted plasma ablation release. Plasma precisely removes tissue at a low temperature, with minimal thermal damage to soft tissues. Temperatures range between $40^{\circ} \mathrm{C}$ and $70^{\circ} \mathrm{C}$ with penetration of less than $1100 \mu \mathrm{m} .^{8}$

Excision can cause reformation of the web. Fibrin glue is a useful material for treating adhesions. Its use for the prevention of adhesion and promotion of wound healing has been recently reported. Kitahara described fibrin glue usage for vocal fold injuries. ${ }^{9}$ Sato used fibrin glue after laser arytenoidectomy for bilateral vocal fold fixation. ${ }^{10}$ We used fibrin glue to cover the raw surfaces of true vocal folds after the web excision to prevent reformation of web due to adhesions which is being reported for the first time in literature.

\section{Conclusion}

Congenital glottic webs are rare anomalies that are usually symptomatic within the first few months of life. Various techniques are available for surgical correction. Endoscope-assisted plasma ablation followed by topical application of fibrin glue seems to be a promising treatment for the management of glottic web with no subglottic extension.

\section{Informed Consent}

An informed consent was obtained from the patient included in the study.

\section{References}

1. Holinger PH, Brown WT. LVI congenital webs, cysts, laryngoceles and other anomalies of the larynx. Ann Otol, Rhinol Laryngol 1967;76(4):744-752. DOI: 10.1177/000348946707600402.

2. Benjamin B. Congenital laryngeal webs. Ann Otol, Rhinol Laryngol 1983;92(4):317-326. DOI: 10.1177/000348948309200401. 
3. Henick DH, Holinger LD. Laryngeal development. In Diagnosis and Treatment of Voice Disorders. San Diego, CA: Plural Publishing; 2006. pp. 21-30.

4. Miyamoto RC, Cotton RT, Rope AF, et al. Association of anterior glottic webs with velocardiofacial syndrome (chromosome $22 q 11$. 2 deletion). Otolaryngology-Head and Neck Surgery 2004;130(4): 415-417. DOI: 10.1016/j.otohns.2003.12.014.

5. Cohen SR. Congenital glottic webs in children: a retrospective review of 51 patients. Annal Otol, Rhinol Laryngol 1985;94(6_suppl): 2-16.

6. Milczuk HA, Smith JD, Everts EC. Congenital laryngeal webs: surgical management and clinical embryology. Int J Pediatr Otorhinolary 2000;52(1):1-9. DOI: 10.1016/s0165-5876(99)00284-0.
7. Ochi JW, Evans JNG, Bailey CM. Paediatric airway reconstruction at great ormond street hospital:a 10-year review in laryngotracheoplasty and laryngotracheal reconstruction. Ann Otol Rhinol Laryngol 1992;101(6):465-468. DOI: 10.1177/000348949210100602.

8. Virk RS, Mathew JL, Behera S, et al. Endoscopic assisted coblation of congenital vallecular cyst-A novel technique. Indian J Pediat 2016;83(8):888-889. DOI: 10.1007/s12098-016-2095-1.

9. Kitahara $S$, Masuda $Y$, Kitagawa $Y$. Vocal fold injury following endotracheal intubation. J Laryngol Otol 2005;119(10):825-827. DOI: 10.1258/002221505774481192.

10. Sato $\mathrm{K}$, Umeno $\mathrm{H}$, Nakashima T. Laser arytenoidectomy for bilateral median vocal fold fixation. Laryngoscope 2001;111(1):168-171. DOI 10.1097/00005537-200101000-00029. 